\title{
Battlefield in Flanders over funding
}

\section{London}

IN a display more reminiscent of militant French farmers than sober Belgian researchers, some 5,000 Flemish scientists took to the streets of Brussels last Thursday (6 February) to protest against the science policy of the regional Flemish government.

The academic pressure group that organized the demonstration, Focus Research, says that Belgian academics have always been poorly funded compared with their neighbours in France, Germany and the Netherlands. But the group claims that the situation for Flemish academics has gone from bad to worse since 1988 , when Belgium moved sharply towards a federal constitution that gave the regional governments in Flemish-speaking Flanders and French-speaking Wallonia effective control over the country's science policy.

The two communities come from different cultural traditions. The Flemish north identifies closely with the Netherlands, while the Walloon south is tied to France. By 1988 the regions' economies had diverged strongly, with Flanders emerging as a centre for high-technology ventures, while Wallonia struggled on with its traditional heavy industry.

The solution then was to divide Belgium into three semi-autonomous regions: Flanders, Wallonia and bilingual Brussels, the state capital and administrative centre of the European Communities (EC). Since then, responsibility for domestic policy - including science — has been passed in large part to the regional governments. In Flanders, for example, the Flemish government now controls about 80 per cent of public funding for science in the region.

Kris Thielemans, an immunologist from the Flemish Free University of Brussels and president of Focus Research, believes this federalization has damaged Flemish science. Since 1988, he says, the Flemish government has neglected fundamental research in the universities at the expense of several costly and high-profile applied research programmes. (Following the lead of the EC, schemes to underpin the information technology industry have been prominent.)

Last week's unprecedented show of public dissent was triggered by two events late last year. In December, the Flemish government decided to slash its funding for high-energy and nuclear physics. At the same time, it ended a scheme that offered tenured research-only positions at universities for the cream of Flemish scientists. The 200 people already benefiting from the scheme will not be removed, but they are expected to come under pressure to take up new jobs in industry, or as university lecturers.

Even more worrying, says Thielemans, is the negative message that the new policies have sent to recent graduates at a time "we need to attract more people". The cuts

ent advisory Council on Science Policy, sympathizes with Focus Research's protest. "Fundamental research has lagged behind. That's clear," he says. Roos argues that the Flemish government has also tried to meddle in the detailed management of Flemish research, putting political appointees into lowly administrative positions. Roos also points out that there is so far no equivalent to his Council in Wallonia.

But Roos believes that the sorry state of Flemish science predates the changes of 1988. "Federalization is not the cause of the problem," he says. Although many Flemish academics look enviously towards their counterparts in Wallonia, Roos says, the underlying situation is little different: in both regions, public spending on science as a proportion of national wealth is about half that spent by its neighbour, the Netherlands. Walloon researchers also are ripe for a protest march, he says, if their government made a single unpopular science policy decision.

The organizers of last week's demonstration (which was accompanied by strike action at Flanders' universities) believe that media coverage will help their cause. "People

in nuclear and particle physics, while specific to those disciplines, are severe. Raymond Gaftmans, a theoretical highenergy physicist from the Catholic University of Leuven, says that some of his experimental colleagues will find their funds cut by as much as 90 per cent.

Thielemans is also concerned that the continuing process of federalization could make obsolete Belgium's main grant-making agency, the National Fund for Scientific Research. The fund's budget is already split in two - 55 per cent comes from the Flemish government and is spent in Flanders, while the remainder comes from the Walloon government, to support research in Wallonia. Given this division, replacing the National Fund with separate regional agencies seems logical enough, but Thielemans fears that the regional bodies might not follow the National Fund's system of grant evaluation. "We're afraid that a working system will be replaced by something new, with no experience of peer review", he says.

Geff Roos, a materials engineer from the Catholic University of Leuven who heads the Flemish government's independ- are talking about science," says Patrick Callaerts, a Drosophila embryologist from the Catholic University of Leuven. "That wasn't the case before." Indeed, the main criticism levelled in the Belgian press was that the demonstrators did not shout loudly enough. "It was very civilized," says Filip Volckaert, a zoologist colleague of Callaerts', who says that the presence of many senior university officials introduced a strong measure of restraint.

Flemish researchers are now waiting to see if their protest brings about change. A new coalition Flemish government was installed only in late January, after elections last November. (Attempts to form a coalition national government, from a parliament elected on the same polling day, are still foundering.) Eventually Focus Research wants the Flanders government to double its spending on research. One positive sign is that the new Flemish prime minister, Luc van den Brande, has promised to take responsibility for the region's science policy. But this gesture must be backed by positive action to pacify Focus Research. "We'll be watching him," Callaerts promises.

Peter Aldhous 